December 2014

\title{
Copyright, Fair Use and the Digital Age in Academic Libraries: A Review of the Literature
}

Amanda McCormick

SUNY Buffalo, mccormickafm@yahoo.com

Follow this and additional works at: https://scholarworks.sjsu.edu/ischoolsrj

Part of the Collection Development and Management Commons, Scholarly Communication Commons, and the Scholarly Publishing Commons

\section{Recommended Citation}

McCormick, A. (2014). Copyright, Fair Use and the Digital Age in Academic Libraries: A Review of the Literature. School of Information Student Research Journal, 4(2). https://doi.org/10.31979/

2575-2499.040205 Retrieved from https://scholarworks.sjsu.edu/ischoolsrj/vol4/iss2/5

This article is brought to you by the open access Journals at SJSU ScholarWorks. It has been accepted for inclusion in School of Information Student Research Journal by an authorized administrator of SJSU ScholarWorks. For more information, please contact scholarworks@sjsu.edu. 


\title{
Copyright, Fair Use and the Digital Age in Academic Libraries: A Review of the Literature
}

\begin{abstract}
Copyright law in the United States has gained a certain notoriety for its complexity and ambiguity, which has only been compounded by the evolution (or, some would say, revolution) of print resources to electronic resources. The purpose of this literature review is to review the current understanding of copyright law within the context of academic libraries in universities and colleges. Additionally, this review will describe what issues academic librarians face in complying with copyright law in this new digital age while continuing to perform duties such as processing course reserve materials, developing an institutional repository, and maintaining a digital collection. This literature review emphasizes the need for further and continuing education about copyright law among all members of the campus community, and, in particular, academic librarians.
\end{abstract}

\section{Keywords}

Copyright, fair use, academic libraries, literature review

\section{About Author}

Amanda McCormick is a recent graduate of the MLS program at the University at Buffalo. Ms. McCormick received her law degree from the University at Buffalo and her undergraduate degree from Hobart \& William Smith Colleges. 
When the New York Times (NYT) added a pay wall to its online site this spring, it made front page news. The debate centered on the right of individuals to freely access the NYT's news articles and columns versus the right of the NYT to profit from and protect its work. The argument was not surprising to anyone versed in U.S. copyright law. The digital age has unleashed a new set of problems stemming from the ease of access to information provided by the internet (Wyatt \& Hahn, 2011). The terrain is rough and uncharted; never before have issues of access and protection clashed in such a powerful way. Users of copyrighted material are hard-pressed to stay up to date with the latest regulations and cases. Copyright holders vigorously defend their rights under the copyright law and the penalties for infringement are harsh. The balance between the rights of copyright holders and information users has always been tenuous at best, and, at its worst, is considered to be an "asymmetric distribution of uncertainty" among the parties (Horowitz, 2012, p. 336). The prevalence of internet use has only exacerbated the issue, and misunderstandings of copyright law are common (Wu, Chou, Ke \& Wang, 2010).

Academic libraries and librarians are not immune to these issues. Academic libraries are tasked with providing students and faculty access to copyrighted materials, in addition to storing and exhibiting such material. The overall purpose of this literature review is to review the current understanding of copyright law within the context of academic libraries in American universities and colleges. Additionally, this review will describe what issues academic librarians face in complying with copyright law while performing duties such as processing course reserve materials and developing an institutional repository.

\section{Discussion}

\section{Copyright Law and the Doctrine of Fair Use}

There are reams of literature written about copyright law and the fair use doctrine. This brief overview means to only to provide a general background of the law for the purposes of this literature review. ${ }^{1}$ Grounded in the U.S. Constitution, copyright law is a form of protection for original works of authorship, including "literary, dramatic, musical, architectural, cartographic, choreographic, pantomimic, pictorial, graphic, sculptural, and audiovisual productions" (U.S. Copyright Office, 2012, Title 17 of the United States Code). Copyright provides the holder with a "suite of exclusive rights: the right to reproduce, to make derivative works, to distribute, to publicly perform, and to display" (Davis, 2012). Not all works are protected by the copyright law; some may be aged out of the system or may be protected by a license agreement (e.g., a contract between

\footnotetext{
${ }^{1}$ An excellent text on copyright law: Crews, K. (2012). Copyright law for librarians and educators. Chicago: American Library Association.
} 
parties or a Creative Commons license) or belong to a class of items that are not copyrightable (e.g., government documents).

Carved out of this right is the fair use doctrine, which permits selective copying and distribution of a work in order to preserve, theoretically speaking, society's access to ideas and innovation (Chang, 2007). The fair use doctrine is a list of four factors that must be weighed to determine whether a use should be deemed fair: (1) the purpose and the character of the use; (2) the nature of the copyrighted work; (3) the amount and substantiality of the portion used in relation to the copyrighted work as a whole; and (4) the effect of the use on the potential market for, or value of, the copyrighted work (US Copyright Office, 2012, 17 U.S.C. §107). The fair use doctrine is heavily informed by case law interpretation (Gould, Lipinski, \& Buchanan, 2005; Pressman, 2008).

Renowned Harvard Professor Lawrence Lessig has famously stated that "fair use in America simply means the right to hire a lawyer to defend your right to create" (Horowitz, 2012, p.348). The following criticism of fair use summarizes main issues with the doctrine: "[U]ncertainty is pervasive in the doctrines salient to users of copyrighted works... [u]sers cannot know whether a given use will be adjudicated lawful because the lawfulness of the use turns on answers to nebulous questions, such as whether the use incorporates copyrighted expression or instead just the un-copyrightable idea, whether the use is substantially similar to the copyrighted work, and even if so, whether the use is fair or otherwise justified by laches or copyright misuse" (Horowitz, 2012, p.374). The fair use doctrine is difficult and often litigious terrain.

The fair use doctrine is present within the context of academic libraries. A recent case decided by a district court in Georgia has wide implications for the fair use doctrine on campus. Although the impact of the decision has not yet been studied in published reports, the case holding is worth discussing briefly in this literature review as it may serve as a lead decision on copyright law within the context of academic libraries for many years to come. In Cambridge University Press v. Patton, three publishers sued Georgia State University for fair use violations within its e-reserves policy. The 350-page decision, after an application of the fair use defense to 99 readings, found only 5 cases of copyright infringement. The first and second fair use factors favored GSU every time, suggesting that (1) academic libraries are favored entities because they are nonprofit educational institutions and (2) use is favored when it is applied to scholarly works of non-fiction (Howard, 2012; Smith, The GSU decision - not an easy road for anyone, 2012). The plaintiffs in the case appealed the decision to the 11th Circuit Court of Appeals in September 2012 and the appeal is awaiting decision (Howard, 2013).

\section{Copyright Law on Campus}


The sheer volume of materials written about copyright law would seem to excuse a precise understanding of copyright law; it is a subject that is under constant scrutiny by the courts and legislators as it is a subject that deals with large amounts of money. In 2002, the copyright industries' revenue from licensing fees was approximately equal to $12 \%$ of the total U.S. gross domestic profit, or, $\$ 1.254$ trillion (Chang, 2007). "The internet seems to be the largest library in the world and it is technically like a super photocopier and fax machine in one" (Wu, et al., 2010, p.199) and thus "many of the intellectual property rules and practices that evolved in the world of physical artifacts do not work well in the digital environment" (Smith, Tobia, Howell, Pfeiffer, \& Fitts, 2006, p. 59). How, then, do those operating in a non-profit world - academic librarians, faculty, students understand the precepts of the law and how it is applicable to them. Not well, it seems, as is indicated by the research studies in this area (Gould, et al., 2005; Papp, Matulich, \& Walters, 2010; Smith, et al., 2006; Wu, et al., 2010).

Faculty demonstrated a basic understanding of copyright law and the doctrine of fair use and acknowledged a limited knowledge of the issues. Smith (2006) conducted a comparative survey of two academic health science campuses to determine whether an institutional effort to educate faculty regarding copyright issues would increase understanding of the copyright law. The study was not able to conclusively demonstrate that institutional education had an impact on knowledge about copyright law. Some faculty, however, stated that they would be interested in non-mandatory further instruction (Smith, et al., 2006).

Student assumptions about copyright law and fair use are particularly disconcerting. Papp et al. (2010) surveyed students at the University at Tampa who acknowledged familiarity with the University's Fair Use Policy, which, at that time, was nonexistent. Students were more familiar with what Papp described as "traditional" copyright rules, such as those addressing plagiarism and photocopying textbooks and other print materials. When it came to electronic resources, however, students assumed that an item provided by a professor via email or Blackboard was already "cleared." Papp cited to the following phrases to describe common student attitudes: "If I can Google it, it must be public information that anyone can use however they want" and "I pay a lot of tuition here, so nobody should be monitoring or restricting my use of the campus network" (Papp et al., 2010). The research study conducted by Wu et al. (2010), even though conducted with college students in Taiwan, found similar attitudes present within the student population. The study teased out four main areas of concern: (1) digital resources can be shared; (2) downloaded digital resources are legitimately authorized by the university and permissible; (3) all educational use is fair use; and (4) downloading materials is permissible because students are paying tuition ( $\mathrm{Wu}$, et al., 2010). 
Similar to faculty members, the students were open to further education on copyright law (Papp, et al., 2010; Smith, et al., 2006). Education possibilities included online resources, printed resources and orientation training; additionally, students asked for sites that provided legal alternatives to illegal file sharing (Papp, et al., 2010). It is important to note that neither faculty nor students appear to demonstrate any knowledge of the multitude of licensing agreements in place at the university and how the licenses affected their access to digital information (Papp, et al., 2010; Smith, et al., 2006; Wu, et al., 2010). This is most concerning as licensing agreements seem to be in place for almost every database in an academic library's system.

The same complexities dogging faculty and students do not disappear when one steps into a library. Gould et al. (2005) conducted a study of how members of the American Research Library Association applied copyright policies and examined the nature of the policies in conjunction with the law of fair use. Approximately thirty-six percent $(36 \%)$ of the libraries imposed a limit on the number of pages that may be reproduced without a copyright holders' permission, but almost one third of those respondents did not know the origin of the rule. Established university committees addressing copyright concerns were rare (only 13 of 78 libraries) and almost half of the libraries reported that they had no representative on the committee (Gould, et al., 2005). Disturbingly, the knowledge base of the academic libraries surveyed seemed to extend no further than that of the faculty and students. Gould et al. (2005) repeatedly stated that the policies were inadequate and that fair use policies must rely on case law as well as the copyright statutes and regulations. It is worth noting that the Association of Research Libraries issued a Code of Best Practices in Fair Use for Academic and Research Libraries in January 2012 (Association of Research Libraries, 2012). Further research may study how this Code of Best Practices impacted academic librarians' knowledge and practices.

\section{Academic Libraries and Copyright Law}

This section of the review will describe what issues academic librarians face in complying with copyright law while performing duties such as processing course reserve materials, developing an institutional repository, providing educational classes to faculty and students about copyright law, and maintaining digital collections.

Processing Reserves. An academic library may serve as the university's copyright center, providing obvious services -such as general copyright law education- but also processing library reserves (such as supplementary print and electronic materials for courses) (Bridgewater, 2008; Quartey, 2007; Wagner, 2008). This process involves compiling faculty members' requests and reviewing the request for compliance with fair use standards (for example, one university 
refers to copyright law regulation H.R. 2223 and one refers to university reserve policies). If the staff believes that the request exceeds fair use guidelines, the staff will contact the Copyright Clearance Center (CCC) or the copyright holder (Bridgewater, 2008; Wagner, 2008). The CCC bills itself as "a global rights broker for the world's most sought after materials, including in- and out-of-print books, journals, newspapers, magazines, movies, television shows, images, blogs and ebooks" (Copyright Clearance Center, 2012). The CCC academic license extends to approximately 200 publishers (Fineberg, 2009).

There is a concern, however, that libraries, instead of asserting fair use rights, will default to seeking permission from licensing agreements or a business such as the CCC (Chang, 2007; Fineberg, 2009). Fair use is in danger of being supplanted by "authentication, clickwrap licenses, and pay-per-use" (Chang, 2007, p.182). For example, Fineberg (2009) sampled three licensing contracts, and while none mentioned "course management systems" specifically, the intent of the agreements leans toward granting access to license holders. On first glance, this may appear to be a positive factor as it means a library will be less likely to be cited for infringement when it is acting within the boundaries of a license agreement. A license agreement, however, deprives users of the right to assert the first sale doctrine, which effectively transforms a document from a material to a right (Chang, 2007). Moreover, a license deprives users of anonymity (Chang, 2007). Although licenses are billed as beneficial to copyright users, it appears that a license acts merely as a wolf in sheep's clothing: there is no safety in willingly compromising a user's legal rights under federal copyright law.

Although it is difficult to (legally) bypass a license agreement, creative librarians are already searching for cost-cutting measures that are in compliance with standard copyright law. A recent study has demonstrated that it was more cost effective to order inter-library loan articles that required copyright royalty payments on an individual "pay-per-view" basis (Brown, 2012). The University of Nebraska's Medical Center's McGoogan Library of Medicine realized savings of over $\$ 14,000$ and $\$ 18,000$ in fiscal years 2009 and 2010 (nearly a 40\% decrease in costs each FY) by utilizing the PPV service and not the standard interlibrary loan method (Brown, 2012). Alternatively, it has been argued that within the context of scholarly articles, academic libraries should adopt a "liberal approach to fair use," in which a library first pays for a scholarly article, thus compensating a publisher for vetting and distribution, and retaining ownership of the article under the first sale doctrine (Davis, 2012). After all, Davis (2012) argues, scholars have donated their work to the publisher and are not reaping profits when they distribute fairly purchased articles to students. This would be an interesting theory to test. 
Institutional repositories. Copyright law also arises in the context of building an institutional repository. An institutional repository ("IR") stores the scholarly record of a university or college; currently, there are approximately 2,000 in place worldwide (Hanlon \& Ramirez, 2011). ${ }^{2}$ A study conducted at Utah State University examined the feasibility of utilizing subject librarian staff for the purposes of facilitating copyright clearance for works, preparing metadata for access to the works, and uploading the full-text work (Leary, Lundstrom, \& Martin, 2012). The use of the librarians was meant to decrease the workload on the faculty while at the same time encouraging the faculty to contribute to the institutional repository. The pilot program was a success (Leary, et al., 2012). Generally, librarians and library staff are utilized to address copyright clearance issues and are tasked with contacting publishers for permission to publish in an IR (Hanlon, et al., 2011).

The libraries discussed in the Bridgewater (2008), Leary (2012) and Wagner (2008) case studies reported increased workload but general overall satisfaction with the new process as it increased knowledge about copyright and related issues (such as the impact of "permission fees" on departmental budgets and increased knowledge of what is being taught in classrooms). The process also assisted in developing bridges between the faculty and the librarians (Bridgewater, 2008; Leary, 2012; Wagner, 2008). Copyright clearance procedures, however, are still in the "formative" stage. The Hanlon et al. (2011) study, which reviewed international and statewide practices, suggests that the library profession consider "developing IR copyright clearance 'best practices' in order to supplement and augment existing copyright directories" and thus increase availability to open access scholarship and author engagement in the process.

Copyright law education. Libraries must play an increased role in copyright law education; this is clear (Graveline, 2011; Quartey, 2007; Wyatt et al., 2011). Case studies from universities point to the need to educate the library staff; promote 'brown bag" sessions in the library discussing copyright law; and arranging a copyright law workshop for faculty (Graveline, 2011). A case study from Brigham Young University, a school acknowledged to be ahead of the curve with regard to copyright law education (Papp, 2010), demonstrates the amount of preparation and planning required to implement a successful program (Quartey, 2007). University administration buy-in was sought, and then the program was intensely marketed (targeted emails, presentations, handouts, pens with slogan,

\footnotetext{
${ }^{2}$ According to OpenDOAR (Directory of Open Access Repositories), there are approximately 396 IRs in the United States as of November 2012.

http://www.opendoar.org/find.php
} 
"Get a grip on Copyright!") and the population was educated (online tutorials) (Quartey, 2007). Student populations may be more amenable to learning about copyright law through Web 2.0 social technologies, such as YouTube (podcasts) and even Facebook (reference services) (Cassidy, Britsch, Griffin, Manolovitz, Shen, \& Turney, 2011).

Digital library collections. The research on this topic is sparse at this time, which may be due to the relative "newness" of digital libraries. Digital library collections are groups of materials organized and selected based on a common theme, which are then compiled into an online database or webpage. It is generally a static collection of resources, more similar to books in the archives than a newsletter on a webpage. Schlosser (2009) surveyed over 700 digital collections to determine if a copyright statement was present, and if so, what the copyright statement stated. The study argued that academic libraries, as educational institutions and stewards of public access to knowledge, have a duty to educate users of digital collections regarding copyright issues. Disappointingly, the results were similar to the results that researchers discovered when researching students, faculty members and academic librarians' knowledge of copyright law (Smith, et al., 2006; Papp, et al., 2010; Wu, et al., 2010, Gould, et al., 2006). The statements were incomplete, vague or incorrect (e.g. asserting copyright over digital reproductions of a two-dimensional item) (Schlosser, 2009). These findings are not entirely surprising, considering the high likelihood that individuals building a digital collection are the same individuals employed by academic libraries, which the previously discussed studies found did not have a satisfactory grip on the principles of copyright law.

\section{Conclusion}

This literature review provided an overview of the current understanding of copyright law within the context of academic libraries in American universities and colleges. The literature discussed in this review emphasized the need for further education about copyright law among all members of the campus community, and, in particular, academic librarians. Academic librarians are stewards of information on campus; the library is the main access point through which information flows. Although it is impractical to expect academic librarians to keep current with the massive amount of literature discussing copyright law, surely more than a rudimentary knowledge is needed. The literature suggests that the role of the academic librarian is central to the functioning of a university/college library. As such, an academic librarian must be educated about copyright law standards - not only to protect the library and the university, but to protect the faculty and students and staff . . . and even protect the much-maligned copyright holders. The development of educational programs centered on copyright law within the context of academic libraries will be crucial to the understanding of the law among librarians. 
School of Information Student Research Journal, Vol. 4, Iss. 2 [2014], Art. 5

https://scholarworks.sjsu.edu/ischoolsrj/vol4/iss $2 / 5$

DOI: 10.31979/2575-2499.040205 


\section{References}

About CCC: Introduction. (2012). Retrieved from Copyright Clearance Center: http://www.copyright.com/content/cc3/en/toolbar/aboutUs.html

Association of Research Libraries. (2012). Code of best practices for fair use in academic and research libraries. Retrieved from Association of Research Libraries: http://www.arl.org/pp/ppcopyright/codefairuse/code/index.shtml

Bridgewater, R. (2008). Shifting responsibility for electronic reserves copyright permissions from the academic departments to the library: from confusion to cooperation. Journal of Interlibrary Loan, Document Delivery \& Electronic Reserve, 18(2), 141-152.

Brown, H. (2012). Pay-per-view in interlibrary loan: a case study. Journal of the Americal Medical Library Association, 100(2), 98-103.

Cassidy, E., Britsch, J., Griffin, G., Manolovitz, T., Shen, L., \& Turney, L. (2011). Higher education and emerging technologies: student usage, preferences, and lessons for library services. Reference \& User Services Quarterly, 50(4), 380-391.

Chang, Y. (2007). Looking for zero-sum or win-win outcomes: a game theoretical analysis of the fair use debate. International Journal of Law and Informational Technology, 16(2), 176-204.

Davis, A. (2012). Fair use: articulating the liberal approach. Libraries and the Academy, 12(2), 121-137.

Fineberg, T. (2009). Copyright and course management systems. Libri, 59, 238247.

Gould, T., Lipinski, T., \& Buchanan, E. (2005). Copyright policies and the deciphering of fair use in the creation of reserves at university libraries. The Journal of Academic Librarianship, 31(3), 182-197.

Graveline, J. (2011). Copyright and academia: launching a successful copyright education program. College \& Undergraduate Libraries, 18, 92-96.

Hanlon, A., \& Ramirez, M. (2011). Asking for permission: a survey of copyright workflows for institutional repositories. Libraries and the Academy, 11(2), 683-702. 
Horowitz, S. (2012). Copyright's asymmetic uncertainty. University of Chicago Law Review, 79, 331-385.

Howard, J. (2012, May 13). Long-awaited ruling in copyright case mostly favors Georgia State $U$. Retrieved from Chronicle of Higher Education: https://chronicle.com/article/Long-Awaited-Ruling-in/131859

Howard, J. (2013, February 1). Publishers and library groups spar in appeal to ruling on electronic course reserves. Retrieved from Chronicle of Higher Education: http://chronicle.com/article/PublishersLibrary-Groups/136995

Leary, H., Lundstrom, K., \& Martin, P. (2012). Copyright solutions for institutional repositories: a collaboration with subject librarians. Journal of Library Innovation, 3(1), 101-110.

Papp, R., Matulich, E., Walters, M., \& McMurrian, R. (2010). Campus perceptions of fair use violations: implications for university policy development. Research in Higher Education Journal, 9, 1-9.

Pressman, R. (2008). Fair use: law, ethics and librarians. Journal of Library Administration, 47(3-4), 89-110.

Quartey, S. (2007). Developing a campus copyright education program: conquering the challenge. Journal of Interlibrary Loan, Document Delivery \& Electronic Reserve, 18(1), 93-100.

Schlosser, M. (2009). Unless otherwise indicated: a survey of copyright statements on digital library collections. College \& Research Libraries, 70(4), 371-385.

Smith, K. (2012, May 12). The GSU decision - not an easy road for anyone. Retrieved from Duke University Libraries Scholarly Communications @ Duke: http://blogs.library.duke.edu/scholcomm/2012/05/12/the-gsudecision-not-an-easy-road-for-anyone

Smith, K., Tobia, R. P., Howell, L., Pfeiffer, S., \& Fitts, M. (2006). Copyright knowledge of faculty at two academic health science campuses: results of a survey. Serials Review, 32(2), 59-67.

Wagner, V. (2008). Processing reserves, seeking permissions and engaging the campus: how the library serves as the copyright touchstone. Journal of Interlibrary Loan, Document Delivery \& Electronic Reserves, 18(2), 247254. 
Wu, H., Chou, C., Ke, H., \& Wang, M. (2010). College students' misunderstandings about copyright laws for digital library resources. The Electronic Library, 28(2), 197-209.

Wyatt, A., \& Hahn, S. (2011). Copyright concerns triggered by web 2.0 uses. Reference Services Review, 39(2), 303-317. 